T.I Туркот // Наукові записки. Серія «Педагогічні науки». - Кіровоград : РВіД КДПУ ім. Винниченка, 2012. - Вип. 76. - ч.2 - С.138-143. 11. Коновал А. А., Туркот Т. И. Новая модель организации самостоятельной учебной деятельности студентов в современной информационно-образовательной среде вуза / Коновал Александр Андреевич, Туркот Татьяна Ивановна // Информация и образование: границы коммуникаций INFO, 11: Сборник научных трудов №4 (12). - Горно-Алтайск: РИО ГАГУ, 2012. - С.37-39. 12. Малихін О.В. Організація самостійної навчальної діяльності студентів вищих педагогічних навчальних закладів: теоретико-методологічний аспект: [монографія] / Олександр Володимирович Малихін. - Кривий Ріг: Видавничий дім, 2009. - 307 с. 13. Маткин В.В. Ценностносинергетический подход и его реализация в процессе педагогической подготовки будущих учителей / В.В. Маткин // Наука и школа. - 2001. - №6 - c.10-12. 14.Рахимов А.3. Педагогическая акмеология: наука о закономерностях достижения профессиональной вершины / Рахимов А.3. - Уфа : БашГПУ, 1999. - 246 с. 15. Сулим І.Ф. Методологічні засади організації самостійної роботи студентів педагогічних коледжів США / Сулим І.Ф. // Наукові записки. Серія: Педагогіка і психологія. Вінницький державний педагогічний університет ім. Коцюбинського, 2005. -№15. - С.116-119. 16. Сулим І.Ф. Структурування змісту освіти в процесі організації самостійної позааудиторної роботи студентів педагогічних коледжів США / І.Ф. Сулим // Наукові записки. Серія: Педагогіка і психологія. Вінницький державний педагогічний університет ім. Коцюбинського. - 2005. - №13. С.133-135. 17. Сулим І.Ф. Мотивація забезпечення самостійної позааудиторної роботи студентів педагогічних коледжів США / І.Ф. Сулим // Наукові записки. Серія: Педагогіка і психологія. Вінницький державний педагогічний університет ім. Коцюбинського. - 2005. - №12. - C.115-117. 18. Tyler R. Basic Principles of Corriculum and Justruction. - Chicago: Univ. of Chicago. Press, 1979. - 216 p.

УДК 377:614.253.5:174

Олена Кравченко

\title{
ФОРМУВАННЯ ПРОФЕСІЙНОЇ ЕТИКИ МАЙБУТНІХ МЕДИЧНИХ СЕСТЕР У НАВЧАЛЬНО-ВИХОВНОМУ ПРОЦЕСІ МЕДИЧНОГО КОЛЕДЖУ: МЕТОДОЛОГІЧНІ ПІДХОДИ
}

Кравченко О. П. Формування професійної етики майбутніх медичних сестер у навчальновиховному процесі медичного коледжу: методологічні підходи.

У статті схарактеризовано компетентнісний, культурологічний, аксіологічний підходи до формування професійної етики майбутніх медичних сестер. Запропоновано структурнозмістову модель та комплекс взаємопов'язаних педагогічних умов формування професійної етики майбутніх медичних сестер у навчально-виховному процесі медичного коледжу.

Ключові слова: професійна етика, майбутня медична сестра, компетентнісний, культурологічний, аксіологічний підходи.

Кравченко Е. П. Формирование профессиональной этики будущих медицинских сестер в учебно-воспитательном процессе медицинского колледжа: методологические подходы.

В статье охарактеризованы компетентностный, культурологический, аксиологический подходы к формированию профессиональной этики будущих медицинских сестер. Предложено структурно-содержательную модель и комплекс взаимосвязанных педагогических условий формирования профессиональной этики будущих медицинских сестер в учебновоспитательном процессе медицинского колледжа.

Ключевые слова: профессиональная этика, будущая медицинская сестра, компетентностный, культурологический, аксиологический подходы.

Kravchenko O. P. Formation of the future nurses ' professional ethics in the educational process of medical college: methodological approaches.

The article determined competence, cultural, axiological approaches to professional ethics of future nurses. Based on the above mentioned approaches structural and semantic model is proposed and a set of interrelated pedagogical conditions of formation of future nurses professional ethics in the educational process of medical college.

Key words: professional ethics, future nurse, competence, cultural, axiological approaches.

Сьогодення з його динамічним потоком інформації й мобільними технологіями вимагає від медичної сестри швидкого виконання маніпуляцій і володіння технічними засобами. Відтак 
професійна діяльність таких фахівців має охоплювати морально-етичну домінанту. Ідеться про такі складники професійної етики медичної сестри, як: відповідальність, повага, совість, честь, гідність, ввічливість, забезпечення прав пацієнта, уважність, чуйність, приязність, витримка та співчуття. До того ж сучасна медична сестра повинна бути завжди зібраною, врівноваженою.

Від сформованої професійної етики медичної сестри залежить довіра до системи медичного обслуговування загалом, довіра і ставлення пацієнта та його родини до конкретної лікарні в місті, області зокрема. Однак, аналіз сучасної практики підготовки в медичних коледжах засвідчує: професійно-етичний аспект у формуванні професійної компетентності цих медичних фахівців часто недооцінюється. Нерідко трапляється, коли медсестри, особливо 3 великим досвідом роботи, припускаються публічних оцінювань призначенням лікарів, нетактовно поводяться із хворим чи рідними; молоді фахівці та новачки іноді відчувають неетичне, зневажливе ставлення до себе санітарок, сестер-господинь тощо [1]. 3 огляду на означені проблеми особливої актуальності набуває дослідження методологічних підходів до формування професійної етики майбутніх медичних сестер у навчально-виховному процесі медичного коледжу.

У теорії та практиці вищої освіти накопичено досвід, що може стати основою модернізації професійної підготовки й формування професійної етики майбутніх медичних сестер. Положення щодо підготовки майбутніх медичних сестер представлено в «Концепції розвитку охорони здоров'я населення України» (2000), у законі України «Про вищу освіту», «Національній доктрині розвитку освіти». Психолого-педагогічні основи дослідження процесу формування професійної етики розглянуто в наукових працях І. Беха, Л. Кондрашової, В. Семиченко, Л. Хоружої. Важливими в контексті дослідження є праці про специфічні особливості формування особистості медичного працівника (Є. Вагнер, Ю. Віленський, О. Грандо, О. Громов, П. Назар, О. Орлов, В. Петровський, Л. Пиріг, І. Шамов).

Мета статті: охарактеризувати особливості формування професійної етики майбутніх медичних сестер у контексті компетентнісного, культурологічного, аксіологічного підходів.

Одним із стратегічних напрямків реформування медичної освіти визнано компетентнісний підхід, визначальними складниками якого є «компетенції», «компетентності», «професійна компетентність». Згідно з визначенням Міжнародного департаменту стандартів для навчання, досягнення та освіти, поняття компетентності витлумачується як спроможність кваліфікованого здійснення діяльності. Компетентності передбачають наявність сукупності знань, навичок та ставлень, які надають особистості змогу ефективно здійснювати діяльність або виконувати певні функції, що відповідають визначеним стандартам у сфері певної професії або виді діяльності [4; 7]. У цьому контексті привертає увагу і визначення, запропоноване С. Гончаренком. Науковець розглядає компетентність як коло питань, у яких людина добре розуміється; набуває знання не лише під час вивчення предмета або групи предметів, а й за допомогою засобів неформальної освіти та внаслідок впливу оточення, що становить духовноетичну основу життєдіяльності [1, с. 231].

3-поміж восьми ключових компетенцій для навчання впродовж життя (вивчати - иукати думати - співпрацювати - діяти - адаптуватися) робоча група 3 підготовки звіту Європейській раді у Стокгольмі та Єврокомісії визначила загальну культуру та етику / культурну компетенцію [5]. В Україні поміж ключових компетентностей як орієнтирів для виявлення результативності освітнього процесу також виокремлюють валеологічно-оздоровчу.

Основними ідеями компетентнісного підходу, як наголошують російські дослідники А. Хуторський та В. Краєвський, $є$ такі: поняття компетентності охоплює не тільки когнітивний i операційно-технологічний складники, а й мотиваційний, етичний, соціальний та поведінковий; поняття компетентності включає результати навчання (знання й уміння), систему ціннісних орієнтацій, звичок тощо; компетентності формуються в процесі навчання, i не лише в середній та вищій школах, а й під впливом родини, друзів, роботи, політики, релігії, культури та ін.; реалізація компетентнісного підходу залежить від загальної освітньокультурної ситуації, в якій живе й розвивається людина [6, с. 7].

Узагальнення дослідницьких позицій (Т. Браже, І. Зязюн, А. Маркова, В. Радул) надає підстави стверджувати, що професійна компетентність фахівців, які працюють у системі «людина - людина», визначається не лише базовими знаннями й уміннями, а й ціннісними орієнтаціями фахівця, мотивами його діяльності, усвідомленням себе у довкіллі, стилем взаємодії з людьми, 
загальною культурою, здатністю до розвитку свого творчого потенціалу [2, с. 14]. Професійну компетентність медичної сестри характеризуємо як сукупність професійних знань, умінь i навичок, професійно-особистісних якостей, що визначають внутрішню готовність здійснювати професійну діяльність на основі кваліфікаційних вимог та морально-етичних норм.

Розглядаючи особливості формування професійної етики майбутніх медичних сестер і проектуючи модель процесу в умовах навчально-виховного коледжу, враховуємо культурологічний підхід. Культурологічний підхід дозволяє розглядати професійну підготовку майбутніх медичних сестер як сукупність культурних компонентів на широкому культурному тлі соціуму з урахуванням культурної ситуації. Відповідно, процес навчання має сприяти створенню оптимальних умов засвоєння загальнолюдської й національної культури, усвідомленню самореалізації особистістю культурних потреб, інтересів і здібностей.

Освітньо-виховне середовище медичного коледжу має стати культурно-освітнім. Ідеться, зокрема, і про дизайн приміщень, символічне наповнення простору (настінна, стендова, знакова та інша інформація), і про використання відповідних концепцій навчання і виховання, навчальних програм, планів, підручників, і різноманітних форм і методів організації навчання, освітні цінності, стиль викладання, наявність умов для вільного спілкування у групі, в коледжі між викладачами та студентами. Взаємодії особистостей в освітньо-виховному середовищі сприяють рівень мотивації у студентів до майбутньої професійної діяльності, реалізація діалогу між викладачем і студентом. У межах такого закладу здійснюється культурний розвиток особистості, набуття досвіду культурної поведінки, надання допомоги й підтримки в культурній самоідентифікації та самореалізації творчого потенціалу.

Медична етика як вид професійної етики розглядає принципи регулювання взаємовідносин і норми поведінки медичних працівників. Напевно, жодна професія, окрім, власне, медичної, немає такої авторитетної історичної традиції в осмисленні ії етичних начал щодо обов'язку перед пацієнтом і суспільством. Основні цінності медсестринської етики (милосердя, гуманність, любов і турбота, співчуття, доброзичливість, працьовитість, чемність) прописані у клятві Флоренс Найнтін-Гейл, в Етичному кодексі Міжнародної ради медичних сестер, в Етичному кодексі медичних сестер України. Аксіологічний підхід, застосований задля формування професійної етики майбутніх медичних сестер, передбачає гуманістичну орієнтацію освіти, яка пов'язана 3 набуттям соціокультурного досвіду. Згідно з аксіологічним підходом людина розглядається як найвища цінність суспільства. Особистість медичної сестри розвивається шляхом оволодіння медичною культурою, медсестринської етики як системи цінностей.

Охарактеризовані вище підходи, а також спостереження, опитування, анкетування, тестування, вивчення навчальної, практичної самоосвітньої діяльності, аналіз навчальних посібників та відвіданих занять викладачів з медичних, загальнокультурних, мовних, психологопедагогічних дисциплін надають змогу припускати, що якісне формування професійної етики майбутніх медичних сестер у медичному коледжі можна забезпечити, якщо розробити i впровадити в навчальний процес ВНЗ І-ІІ рівнів акредитації відповідну структурно-змістову модель, а також обгрунтувати комплекс взаємопов'язаних педагогічних умов.

Запропонована модель складається із методологічного, змістового, діяльнісного, діагностувального блоків і реалізується в навчально-виховному процесі медичного коледжу поетапно упродовж усіх трьох років навчання студентів, а результатом $\epsilon$ набутий рівень сформованості професійної етики. У методологічному блоці знаходять виявл заявлені попередньо підходи, дані замовлення ринку праці на підготовку молодших спеціалістів «Сестринська справа» 3 високим рівнем професійної етики, принципи такої підготовки. Змістовий блок складають навчальні дисципліни, збагачені завданнями культурологічного й аксіологічного спрямування, орієнтовані на формування професійної етики студентів, виробнича практика, виховна робота, що спрямовані на професійне самовдосконалення і саморозвиток професійно-етичних якостей у майбутніх медичних сестер. Значною мірою формування морально-етичних якостей майбутніх медичних сестер залежить від ефективності виховної роботи навчального закладу, а також виробничої практики (належить до діяльнісного блоку), цілеспрямованої роботи викладацького складу, їх взаємодії з соціальними інститутами (сім'я, медичні установи, заклади культури тощо). Системно організована виховна робота стимулює свідомий вибір медичної професії і формування медсестринської етики. 
Функціонування запропонованої моделі припускає реалізації комплексу взаємопов'язаних педагогічних умов. Ідеться, зокрема, про створення освітньо-виховного середовища в медичному коледжі; формування мотиваційно-ціннісного ставлення до майбутньої професії; збагачення змісту навчальних дисциплін, виховних заходів, виробничої практики завданнями професійно-етичного спрямування. Педагогічна дія викладачів забезпечує послідовне дотримання зазначених педагогічних умов і спрямовується на виконання педагогічної взаємодії 3 майбутніми молодшими спеціалістами сестринської справи.

Отже, в умовах сьогодення зростають вимоги до таких професійно-етичних якостей майбутніх медичних сестер, як: висока моральність, здатність до емпатії, добропорядність, готовність завжди прийти на допомогу. Здійснений аналіз переконує: процес формування професійної етики у майбутніх медичних сестер буде більш успішним, якщо враховувати компетентнісний, культурологічний, аксіологічний підходи. Так, відповідно до компетентнісного підходу, навчання доцільно спрямувати на формування професійно-етичних умінь; культурологічний підхід дозволяє створити оптимальні умови засвоєння загальнолюдської й національної культури; аксіологічний підхід застосовується задля усвідомлення та самореалізації особистістю своїх культурних потреб, інтересів і здібностей, виховання цінностей майбутньої професії.

У подальших публікаціях маємо на меті подати дослідно-експериментальну перевірку структурно-змістової моделі формування професійної етики майбутніх медичних сестер у медичному коледжі з урахуванням зазначених вище підходів.

\section{Література}

1. Беденко-Зваридчук О. Культура поведінки та етика взаємовідносин у роботі медичної сестри / О. Беденко-Зваридчук // Журнал головної медичної сестри. - 2012.- № 2 / жовтень / [Електронний ресурс _ - Режим доступу: http://medprosvita.com.ua/kultura_povedinki_ta_etika_vza $\%$ D1\%94movidnosin_u_roboti_medichnoji_sestri - Загол. 3 екрану. - Мова польська. 2. Гончаренко С. У. Український педагогічний енциклопедичний словник / С. У. Гончаренко. - Рівне : Волинські обереги, 2011. - 550 с. 3. Зязюн І. А. Філософія поступу і прогнозу освітньої системи / I. А. Зязюн // Педагогічна майстерність: проблеми, пошуки, перспективи: [монографія]. - К.; Глухів : РВВ ГДПУ, 2005. - С. 10 - 18. 4. Каган М. С. Философская теория ценности / М. С. Каган. - С-Пб., 1997. - 205 с. 5. Компетентнісний підхід у сучасній освіті: світовий досвід та українські перспективи: Бібліотека з освітньої політики ; під заг. ред. О. В. Овчарук. - К. : «К.І.С.», 2004. - 90 с. 6. Офіційний сайт ЮНЕСКО : збірка документів. - [Online]. Режим доступу: http: http://aidden.hut/ru.index. 7. Хуторской А. В. Предметное и общепредметное в образовательных стандартах / А. В. Хуторской, А. В. Краевский // Педагогика. - 2003. - № 3. - С. 3-10. 8. Fabre Aurelien Pedajojie scientinque et education / Par Aurelion Fabre. - Parise: Libr., Colin, 1978. - 159 p.

Світлана Луценко

\section{ВИКОРИСТАННЯ МОЖЛИВОСТЕЙ ІНФОРМАЦІЙНИХ ТЕХНОЛОГІЙ В ІННОВАЦІЙНОМУ УПРАВЛІННІ ОСВІТОЮ}

Луценко С. М. Використання можливостей інформаційних технологій в інноваційному управлінні освітою.

У статті розглядаються проблеми запровадження інформаційної системи управління освітою. Звернено увагу на специфіку взаємодії органів місцевого самоврядування, відділів освіти та навчальних закладів при застосуванні ІСУО в Сумській області.

Ключові слова: інформаційні технології, інформаційна система управління освітою, єдине інформаційно-освітнє середовище.

Луценко С. М. Использование возможностей информационных технологий в инновационном управлении образованием.

В статье рассматриваются проблемы внедрения информационной системы управления образованием. Обращено внимание на специфику взаимодействия органов местного самоуправления, отделов образования и учебных заведений во время внедрения ИСУО в Сумской области.

Ключевые слова: информационные технологии, информационная система управления образованием, единое информационно-образовательную среду. 